\title{
Nitrogen Metabolism of an Anoxygenic Filamentous Phototrophic Bacterium Oscillocholris trichoides Strain DG-6
}

\author{
R. N. Ivanovsky ${ }^{a}$ *, N. V. Lebedeva ${ }^{a}$, O. I. Keppen ${ }^{a}$, and T. P. Tourova ${ }^{b}$ \\ ${ }^{a}$ Moscow State University, Moscow, 119191 Russia \\ ${ }^{b}$ Winogradsky Institute of Microbiology, Research Center of Biotechnology, Russian Academy of Sciences, \\ Moscow, 119071 Russia \\ *e-mail:mguru@mail.ru
}

Received February 21, 2021; revised March 22, 2021; accepted March 24, 2021

\begin{abstract}
The possible nitrogen sources for Osc. trichoides DG6, a typical strain of the Oscillochloridaceae family, are ammonium, $\mathrm{N}_{2}$, glutamate, asparagine, glycine, and glutamine. The assimilation of molecular nitrogen occurs with the participation of nitrogenase, the structural gene of which, nif $\mathrm{H}$, is located in the gene cluster which also includes the genes of the nif $\mathrm{D}$ and nif $\mathrm{K}$ nitrogenase subunits and the auxiliary nif $\mathrm{B}$ gene. Considering that nifHBDK clusters have been also annotated in the genomes of other members of the Oscillochloridaceae family, including uncultured and candidate taxa, it can be assumed that the ability to fix nitrogen is a property immanent for this entire family. The pathways for assimilating ammonium in the cells grown using different nitrogen sources may differ. Osc. trichoides DG6 growing in a medium containing ammonium assimilated it with the participation of glutamate dehydrogenase, which is determined by a single gene. The expression product of this gene has dual functionality and can be used to implement the reaction with both NAD and NADP. With the growth of Osc. trichoides DG6 on a medium with glutamate as the only nitrogen source all the enzymes necessary for the implementation of the GS-GOGAT pathway were found in the cells. However, for the glutamine synthetase reaction, ammonium, which was absent in the growth medium, was required. The source of ammonium may be glutamate metabolized through glutamate dehydrogenase.
\end{abstract}

Keywords: anoxygenic filamentous phototrophic bacteria, Oscillochloris, nitrogen metabolism, assimilation of $\mathrm{N}_{2}$ and ammonium

DOI: $10.1134 / \mathrm{S} 0026261721040068$

All currently known anoxygenic filamentous phototrophic bacteria (AFPBs) belong to the phylum Chloroflexi. Members of the order Chloroflexales form a monophyletic lineage that includes the families Chloroflexaceae, Roseiflexaceae, and Oscillochloridaceae. The AFPBs classified into these families differ in terms of photosynthetic machinery composition, capacity for autotrophy, and growth temperature. Members of these families also differ in their nitrogen metabolism (Hanada, 2014).

There is no evidence that any representatives of the phototrophic thermophilic family Roseiflexaceae are capable of utilizing molecular nitrogen as a nitrogen source (Thiel et al., 2017). However, the genomes of Roseiflexus sp. RS1 and Roseiflexus castenholzii contain a cluster of four co-located nifHBDK genes that presumably code for the structural genes of the Mo nitrogenase. It was suggested that the incapacity of these bacteria to grow under diazotrophic conditions results from a lack of supplementary genes that are normally implicated in the biosynthesis and maturation of the functional apoprotein of the nitrogenase (van der Meer et al., 2010; Klatt et al., 2013; Thiel et al., 2017; Nishihara et al., 2018).

Representatives of the family Chloroflexaceae can utilize ammonium and amino acids, such as alanine, glutamate, glutamine, aspartate, glycine, and serine, but not nitrates as the sole nitrogen source (Heda and Madigan, 1986; Hanada, 2014). Nitrogen-fixing capacity and nitrogenase activity were not detected in four Chloroflexus aurantiacus strains which was correlated with their thermophily (Heda and Madigan, 1986; Hanada, 2014). Subsequently, these data were confirmed by analyzing the $C f l$. aurantiacus genome that lacked the structural genes of nitorogenase and nitrate reductase (Tang et al., 2011).

The photoautotrophic bacteria of the family Oscillochloridaceae, which are the main subject of the present work, are mesotrophic microorganisms with a growth optimum of $28-30^{\circ} \mathrm{C}$ (Keppen et al., 1993). The main nitrogen sources for the growth of Oscillochloris trichoides DG-6, the type strain of the family Oscillochloridaceae, are ammonium and the amino acids asparagine, glycine, glutamate, and gluta- 
Table 1. Reactions and the $\mathrm{N}$ metabolism pathway enzymes of Osc. trichoides DG-6 that catalyze them; their activities were measured in this work

\begin{tabular}{l|l|l}
\hline \multicolumn{1}{c|}{ Enzyme } & $\begin{array}{l}\text { Gene locus tag } \\
\text { in the genome } \\
\text { (locus_tag) }\end{array}$ & Reaction \\
\hline Nitrogenase EC 1.18.6.1 & $\begin{array}{l}\text { OSCT_0062 } \\
\text { OSCT_0063 } \\
\text { OSCT_0064 } \\
\text { OSCT_0065 }\end{array}$ & $\mathrm{N}_{2}+8 \mathrm{H}^{+}+8 \mathrm{e}^{-} 16 \mathrm{ATP} \rightarrow 2 \mathrm{NH}_{3}+\mathrm{H}_{2}+16 \mathrm{ADP}+16 \mathrm{P}_{\mathrm{i}}$ \\
\hline $\begin{array}{l}\text { Glutamate dehydrogenase } \\
\text { (GDH) }\end{array}$ & OSCT_0145 & Glutamate $+\mathrm{NAD}(\mathrm{P})^{+}+\mathrm{H}_{2} \mathrm{O} \rightarrow \alpha$-Ketoglutarate $+\mathrm{NAD}(\mathrm{P}) \mathrm{H}+\mathrm{NH}_{3}$ \\
$\begin{array}{l}\text { EC 1.4.1.2; } \\
\text { EC 1.4.1.4 }\end{array}$ & OSCT_1286 & Glutamate $+\mathrm{NH}_{4}+\mathrm{ATP} \rightarrow \mathrm{Glutamine}+$ ADP $+\mathrm{P}_{\mathrm{i}}$ \\
\hline $\begin{array}{l}\text { Glutamine synthetase } \\
\text { (GS) EC 6.3.1.2 }\end{array}$ & OSCT_0551 & 2Glutamate $+\mathrm{NADP}^{+} \rightarrow \mathrm{Glutamine}+\alpha-$ Ketoglutarate $+\mathrm{NADPH}$ \\
\hline $\begin{array}{l}\text { Glutamate synthase } \\
\text { (GOGAT) EC 1.4.1.13 }\end{array}$ & $\begin{array}{l}\text { OSCT_0733 } \\
\text { Glutamate-oxaloacetate }\end{array}$ & Aspartate $+\alpha-$ Ketoglutarate $\rightarrow$ Oxaloacetate + Glutamate \\
transaminase (GOT) & OSCT_1058 & \\
EC 2.6.1.1 & OSCT_1297 & \\
\hline $\begin{array}{l}\text { Glutamate-pyruvate } \\
\text { transaminase (GPT) } \\
\text { EC 2.6.1.2 }\end{array}$ & OSCT_3177 & \\
\hline
\end{tabular}

mine (Keppen et al., 1989). A distinctive feature of Osc. trichoides that sets it apart from bacteria belonging to the genera Roseiflexus and Chloroflexus is its ability to utilize $\mathrm{N}_{2}$ as the sole nitrogen source for its growth (Keppen et al., 1989). Subsequently, amplification and sequencing of the nif $\mathrm{H}$ gene encoding the nitrogenase, the key enzyme of the nitrogenase complex, was carried out; the gene is located on the DNA matrix of three Oscillochloris strains, including Osc. trichoides DG-6 (Tourova et al., 2006).

The goal of the present work was comparative analysis of the genome data that are concerned with the putative nitrogen metabolism processes in cultivable AFPBs of the order Chloroflexales and experimental confirmation of the implementation of these processes by the bacteria of the strain Osc. trichoides DG-6.

\section{MATERIALS AND METHODS}

Bacteria and cultivation conditions. The research subject was the anoxygenic filamentous phototrophic bacterium (AFPB) Osc. trichoides DG-6. Its cultures were grown in a modified DGN medium with a vitamin complex, $0.1 \%$ acetate, $0.1 \%$ bicarbonate, and $0.1 \%$ sulfide (Keppen et al., 1994). The bacterium was cultivated under anaerobic conditions in the light with a magnetic stirrer $(300 \mathrm{rpm})$ at a temperature of $28-$ $30^{\circ} \mathrm{C}$ and a light intensity of $2000 \mathrm{~lx}$ in 500 - $\mathrm{mL}$ screwtop vials. If $\mathrm{N}_{2}$ was used as a nitrogen source, the flasks contained $300 \mathrm{~mL}$ of the medium and molecular nitrogen as the gas phase. The flasks were completely filled with the medium when ammonium or glutamate were used as nitrogen sources.

Obtaining cell extracts. To obtain cell-free extracts of a culture at the end of the exponential growth phase, the culture was centrifuged $\left(9000 \mathrm{rpm}\right.$ at $\left.6-8^{\circ} \mathrm{C}\right)$ and washed with $0.05 \mathrm{M}$ Tris- $\mathrm{HCl}$ buffer ( $\mathrm{pH} 7.5)$; the cells were disintegrated with an X press (LKB, Sweden) at an excess pressure of $10 \mathrm{t} / \mathrm{cm}^{2}$. Intact cells and large fragments were separated by centrifugation at $35000 \mathrm{~g}$ for $1 \mathrm{~h}$. The resulting supernatant was used to determine enzymatic activity.

Determining the enzymatic activity. The reactions of the N metabolism pathways in Osc. trichoides DG-6 and the catalyzing enzymes whose activities were measured in this work are listed in Table 1. The enzymatic activities were determined with a Hitachi 200 spectrophotometer (Hitachi, Japan) from NAD $(\mathrm{P}) \mathrm{H}$ oxidation and $\mathrm{NAD}(\mathrm{P})$ reduction at $340 \mathrm{~nm}$.

The reaction mixtures for determining enzyme activities contained the following:

(1) for glutamate dehydrogenase (GDH): ketoglutarate, $5 \times 10^{-3} \mathrm{M} ; \mathrm{NH}_{4} \mathrm{Cl}, 4 \times 10^{-2} \mathrm{M} ; \mathrm{NAD}(\mathrm{P}) \mathrm{H}$, $2.5 \times 10^{-4} \mathrm{M}$; Tris- $\mathrm{HCl}(\mathrm{pH} 7.5), 5 \times 10^{-2} \mathrm{M}$; 
(2) for glutamate synthase (GOGAT): ketoglutarate, $5 \times 10^{-3} \mathrm{M}$; glutamine, $5 \times 10^{-3} \mathrm{M}$; NAD $(\mathrm{P}) \mathrm{H}$; $2.5 \times 10^{-4} \mathrm{M}$; Tris- $\mathrm{HCl}(\mathrm{pH} 7.5) ; 5 \times 10^{-2} \mathrm{M}$;

(3) for glutamate-oxaloacetate transaminase (GOT): NAD, $2.5 \times 10^{-4} \mathrm{M}$; ketoglutarate, $4 \times 10^{-3} \mathrm{M}$; aspartate, $4 \times 10^{-3} \mathrm{M}$; phosphate buffer ( $\left.\mathrm{pH} 7.4\right), 0.1$ $\mathrm{M}$; malate dehydrogenase, $1.25 \mathrm{mg} / \mathrm{mL}$;

(4) for glutamate-pyruvate transaminase (GPT): NAD, $2 \times 10^{-4} \mathrm{M}$; ketoglutarate, $4 \times 10^{-3} \mathrm{M}$; phosphate buffer $(\mathrm{pH} 7.5), 0.1 \mathrm{M}$; alanine, $8 \times 10^{-3} \mathrm{M}$; lactate dehydrogenase, $1.25 \times 10^{-3} \mathrm{mg} / \mathrm{mL}$;

(5) glutaminase (GA): glutamine, $4 \times 10^{-3} \mathrm{M}$; Tris$\mathrm{HCl}(\mathrm{pH} 7.5), 5 \times 10^{-2} \mathrm{M}$; glutamate dehydrogenase, $0.15 \mathrm{U} / \mathrm{mL}$.

Glutamine synthetase (GS) activity was determined as was described earlier (Ivanovsky and Khatipov, 1994).

All reaction mixtures were supplemented with cell extract containing $1.0-2.0 \mathrm{mg} / \mathrm{mg}$ protein. Proteins were determined by the Lowry method.

Bioinformatic analysis. Reconstruction of the possible pathways of nitrogen metabolism was carried out by comparing the genomes of cultured AFPB strains of the order Chlorofexales, using NCBI (https:// www.ncbi.nlm.nih.gov/genome/), PATRIC (https:// www.patricbrc.org), and KEGG (https://www. genome.jp/kegg/pathway.html) online services. Comparison of the nif gene clusters was performed using the Gene Graphics (https://katlabs.cc/genegraphics/app) online service.

\section{RESULTS AND DISCUSSION}

Potential functional characteristics of nitrogen metabolism of the cultivable AFPB strains of the order Cloroflexales based on comparison of their genomes. Gene set enrichment analysis for nitrogen metabolism and for alanine, aspartate and glutamate metabolism was performed using the KEGG database for the genomes of cultivable strains of the genera Oscillochloris, Chloroflexus, and Roseiflexus (Fig. S1a, S1b).

According to the genome data for all strains to be compared, the heat maps of the putative nitrogen metabolism genes contained glutamate conversion enzymes, such as glutamate synthase (GOGAT) (NAD (P)H) (EC 1.4.1.13); glutamine synthetase (GS) (EC 6.3.1.2), and glutamate dehydrogenase (GDH) in two functional variants that interact with $\mathrm{NADH}$ (EC 1.4.1.2) and NAD(P)H (EC 1.4.1.4), respectively. The same enzymes were present in all tested strains on the heat map of the enzymes of alanine, aspartate, and glutamate metabolism.

The presence of other putative nitrogen metabolism enzymes markedly varied, depending on the taxonomic affiliation of the tested strains. Nitrogenase (EC 1.18.6.1) that is responsible for molecular nitrogen fixation has only been annotated in the genomes of
Table 2. Growth of Osc. trichoides DG-6 on media with various nitrogen sources (mg of protein per $1 \mathrm{~L})$ *

\begin{tabular}{l|c}
\hline \multicolumn{1}{c|}{ Nitrogen source } & Biomass accumulation \\
\hline Ammonium & 23.3 \\
Glutamate & 22.2 \\
Aspartate & 26.0 \\
Asparagine & 11.2 \\
Urea & 23.4 \\
$\mathrm{~N}_{2}$ & 1.2 \\
\hline
\end{tabular}

* The cultivation time was $48 \mathrm{~h}$.

Oscillochloris and Roseiflexus strains, similar to carbonic anhydrase (EC 4.2.1.1). Hydroxylamine reductase (EC 1.7.99.1) has only been annotated for Oscillochloris strains, and nitrate reductase (EC 1.7.99.4), for Roseiflexus strains. Most enzymes of alanine, aspartate, and gluconate metabolism have been annotated in the genomes of all tested strains; however, alanine dehydrogenase (EC 1.4.1.1) has only been annotated in the strains of Roseiflexus and alanine transaminase (EC 2.6.1.2) in the strains of Oscillochloris.

The absence of the genes that determine the enzymes of assimilative and dissimilative nitrate reduction in the genomes of cultivable Chloroflexales and Oscillochloris strains accounts for the earlier experimental data on the incapacity of the AFPBs of these genera to grow on media with oxidized nitrogen compounds. Nevertheless, this confirms the data on utilization of reduced nitrogen compounds (ammonium, urea, glutamate, and a number of amino acids) for the growth of strains belonging to the genera Chloroflexus and Oscillochloris (Heda and Madigan, 1986; Keppen et al., 1993, 2000). The results of comparative genome analysis were consistent with the earlier data on the incapacity of the AFPBs of the genus Chloroflexus to fix molecular nitrogen (Heda and Madigan, 1986) and, conversely, the capacity for nitrogen fixation in the AFPBs of the genus Oscillochloris ( Ivanovsky and Khatipov, 1994; Keppen et al., 1989, 2000).

Nitrogen sources utilized by Osc. trichoides DG-6. Nitrogen sources for Osc. trichoides DG-6 included ammonium, $\mathrm{N}_{2}$, and the amino acids asparagine, glycine, glutamate, and glutamine (Table 2).

Assimilation of molecular nitrogen by Osc. trichoides DG-6. The presence of the nif $\mathrm{H}$ gene that encodes the key enzyme of molecular nitrogen fixation was earlier revealed in experiments on amplifying the gene not only in the type strain DG-6, but also in several closely related strains also classified into the species Osc. trichoides (Tourova et al., 2006). The functional activity of nitrogenase was confirmed by demonstrating the growth of the culture in the presence of $\mathrm{N}_{2}$ as the sole nitrogen source (Keppen et al., 1989). In the 
Table 3. Nitrogenase activity in Osc. trichoides DG-6 (nmoles/min/mg of protein)

\begin{tabular}{l|c|c|c}
\hline Enzyme/growth substrate in the medium & Glutamate, $0.1 \%$ & $\mathrm{NH}_{4}^{+}, 0.1 \%{ }^{+}$ & $\mathrm{N}_{2}$ \\
\hline Nitrogenase & 0.9 & 0.0 & 3.2 \\
\hline
\end{tabular}

present work, nitrogenase activity was observed during the growth of strain DG-6 on $\mathrm{N}_{2}$ by detecting the ability of the cell suspension to reduce acetylene; this activity was repressed by adding reduced nitrogen compounds (Table 3). The nitrogenase enzyme is present on the nitrogen metabolism map in the KEGG database, which is in accordance with the results of analysis of the genome of Osc. trichoides DG-6 (Fig. S2a). Based on these data, the previously detected nitrogenase reductase gene $(n i f \mathrm{H})$ forms a part of the gene cluster (OSCT_0062, OSCT_0063, OSCT_0064, OSCT_0065) that also includes the genes of nitrogenase subunits (nif $\mathrm{D}$ and nifK) and the auxiliary nifB gene (Fig. 1). Therefore, Osc. trichoides DG-6 is currently the only representative of the order Chloroflexales whose capacity for nitrogen fixation has been demonstrated using genome data as well as experimentally. However, the genome data indicate that the recently isolated AFPB species "Candidatus Oscillochloris kuznetsovii" and "Candidatus Oscillochloris fontis," "Candidatus Chloroploca asiatica" and "Candidatus Viridilinea mediisalina" may be capable of diazotrophy, due to the presence of the nitrogenase gene cluster (Grouzdev et al., 2018, 2019; Gaisin et al., 2019a, 2019b, 2020) that is homologous to the nifHBDK cluster of the strain Osc. trichoides GD-6. Taking into account that the nifHBDK clusters were also annotated in the genomes of other represen- tatives of the family Oscillochloridaceae, including uncultured and candidate species, the nitrogen fixation capacity is presumably a feature that is characteristic of the whole family.

Nonetheless, the genomes of cultivable AFPB strains of the genus Roseiflexus also contain a nitrogenase gene cluster that is structurally similar to the nifHBDK cluster of representatives of the genus Oscillochloris, except for the gene overlap detected in them (Fig. 1). No data on the nitrogenase functional activity in cultivable Roseiflexus spp. strains are available. The type strain of Rof. castenholzii cannot grow on $\mathrm{N}_{2}$ as the only nitrogen source (Thiel et al., 2017). However, the aforementioned suggestion that this is due to a lack of other genes, nif $\mathrm{E}$ and nif $\mathrm{N}$ that determine the minimum set of auxiliary proteins for nitrogenase maturation (Dos Santos et al., 2012) becomes dubious, considering the functional activity of an analogous nifHBDK cluster in the strains of Oscillochloris. Presumably, the gene overlap in the cluster indicates a mutation process involving a loss of the functional activity of nitrogenase genes in the strains of the genus Roseiflexus, due to their adaptation to thermophilic environmental conditions.

The experimental evidence of existence of an extremely simplified but still functional cluster of nitrogenase genes might be of paramount importance

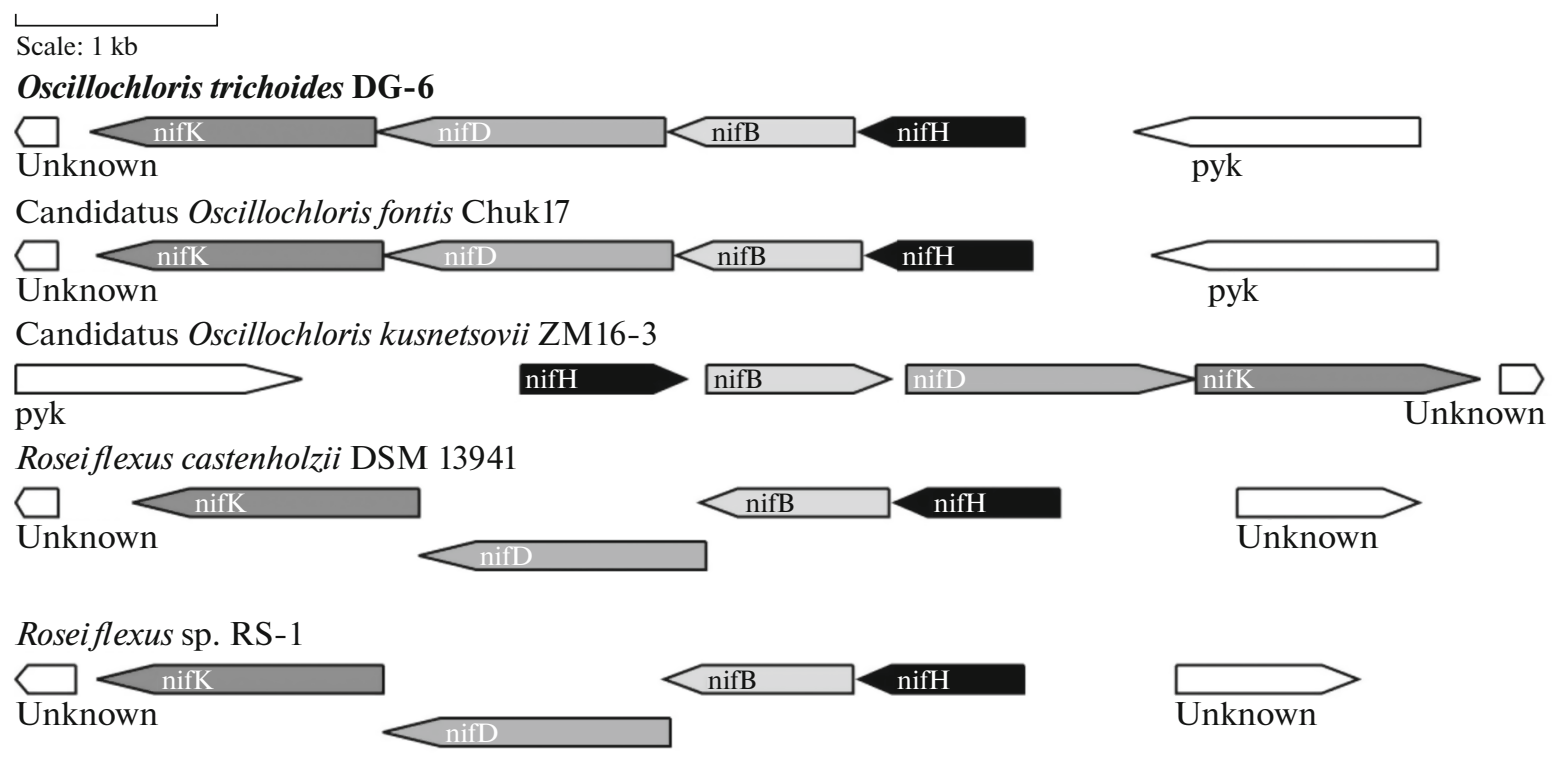

Fig. 1. Structure of the genome clusters containing annotated nif genes in members of the families Oscillochloridaceae and Roseiflexaceae.

MICROBIOLOGY Vol.90 No.4 2021 


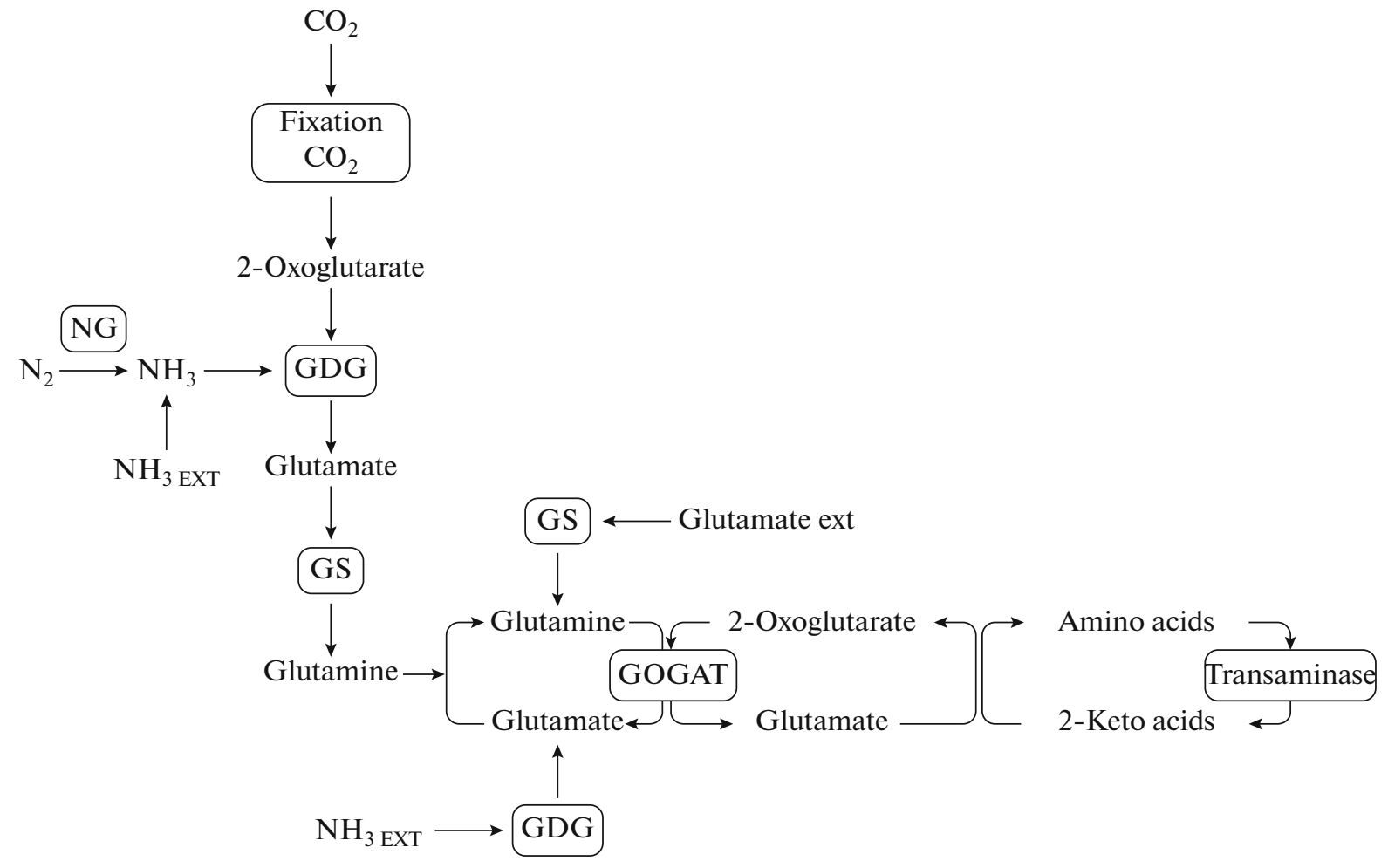

Fig. 2. Nitrogen metabolism in Osc. trichoides DG-6 utilizing various nitrogen sources.

for potential biotechnological developments regarding the implantation of these genes into a plant genome.

Assimilation of reduced nitrogen compounds by Osc. trichoides DG-6. Similar to most phototrophic bacteria, Osc. trichoides DG-6 grows optimally on media with reduced nitrogen compounds (Table 2). The maps of pathways of nitrogen, alanine, aspartate, and glutamate metabolism based on analyzing the Osc. trichoides DG-6 genome in the KEGG database are shown in Figs. S2a, S2b. The activities of respective enzymes in Osc. trichoides DG-6 grown in media with various nitrogen sources were assessed in the present work (Table 2). The results obtained indicate that, despite the presence of all ammonium assimilation pathways-determining genes in the tested genome, the implementation of these pathways in the cells grown with different nitrogen sources may be different (Fig. 2). Similar to other AFPBs, ammonium can be incorporated in Osc. trichoides DG-6 metabolism via the GS-GOGAT pathway. According to genomic data, the enzymes of this pathway, glutamine synthetase (GS, EC 6.3.1.2) and glutamate synthase (GOGAT, EC 1.4.1.13), encoded by one gene each (OSCT_1286 and OSCT_0551, respectively), are present on the metabolism maps in question (Fig. S2a, S2b). However, GS activity was only detectable in the medium with glutamate (Table 4) but not on the media with ammonium, unlike Cfl. aurantiacus, for which the measured activity of this enzyme was even higher in the medium with ammonium than in the medium with glutamate (Kaulen and Klemme, 1983).

According to the data obtained in the present work, Osc. trichoides strain DG-6 growing in the medium with ammonium uses the ammonium assimilation pathway involving glutamate dehydrogenase (Fig. 2). Glutamate dehydrogenases (GDHs: EC 1.4.1.2 and EC 1.4.1.4) are encoded by a single gene (OSCT_0145) that has been annotated in the Osc. trichoides DG-6 genome (Figs. S2a, S2b). The

Table 4. Enzyme activities involved in ammonium assimilation in Osc. trichoides DG-6 (nmol/min mg of protein)

\begin{tabular}{l|c|c}
\hline $\begin{array}{c}\text { Enzyme/nitrogen } \\
\text { source }\end{array}$ & Glutamate, $0.1 \%$ & $\mathrm{NH}_{4}^{+}, 0.1 \%+$ \\
\hline GDH NADH & 3.2 & 6.5 \\
GDH NAD(P)H & 3.2 & 2.0 \\
GOGAT NADH & 1.9 & 2.0 \\
GOGAT NAD(P)H & 0.9 & 2.0 \\
GS & 20.2 & 0.0 \\
GA & 4.0 & 4.9 \\
GOT & 42.1 & 70.5 \\
GPT & 47.3 & 7.8 \\
\hline
\end{tabular}

The enzyme activities were not measured in the cells growing in the medium with molecular nitrogen because insufficient biomass was produced under these conditions. 
product of the gene is characterized by dual substrate specificity: it can use both NAD and NADP for carrying out the process. A twofold increase in activity of the NAD-dependent enzyme isoform in the extracts of ammonium-grown cells may indicate its preferential involvement in assimilating the substrate (Table 4).

If Osc. trichoides DG-6 grows in a medium with glutamate as the sole carbon source, its cells contain all the enzymes that are necessary for implementing the GS-GOGAT pathway (Table 4). However, carrying out the glutamine synthetase reaction requires ammonium that is absent from the medium. The glutamate dehydrogenase reaction can provide the cells with ammonium (Fig. 2), since the activities of both $\mathrm{GDH}$ isoenzymes were detected in the cells grown in the medium with glutamate (Table. 4).

Apparently, the GS-GOGAT pathway in Osc. trichoides is also implemented during nitrogen fixation. However, additional research is necessary for verifying this statement.

The alanine dehydrogenase gene $(\mathrm{ADH}, \mathrm{EC}$ 1.4.1.1) in Osc. trichoides has not been annotated, which rules out the involvement of this enzyme in assimilating ammonium in this AFPB, similar to Cfl. aurantiacus. The gene was not annotated in the Cfl. aurantiacus genome and the enzyme's activity was not detected (Kaulen and Klemme, 1983). However, the alanine transaminase gene (GPT, EC 2.6.1.2) was annotated in Osc. trichoides, which sets Osc. trichoides apart from other cultivated strains of the order Cloroflexales. Its activity was higher in the medium with glutamate than with ammonium, similar to another enzyme, aspartate transaminase (GOT, EC 2.6.1.1) (Table 4). The high activities of transaminating enzymes arfe in conformity with the capacity of Osc. trichoides to utilize amino acids as nitrogen sources for its growth.

The data obtained in this work on the patterns of nitrogen metabolism of Osc. trichoides DG-6 with various nitrogen sources are summed up in Fig. 2.

The conclusion may be drawn that integrated research on the genetic and enzymatic aspects of organic nitrogen metabolism make it possible to elucidate the ecological and evolutionary features of AFPBs of the family Oscillochloridaceae and assessing the applicability of their metabolic potential in biotechnology.

\section{FUNDING}

This work was partially supported by the Russian Foundation for Basic Research (grant no. 20-54-12031 NNIO_a).

\section{COMPLIANCE WITH ETHICAL STANDARDS}

The authors declare that they have no conflict of interest. This article does not contain any studies involving ani- mals or human participants performed by any of the authors.

\section{SUPPLEMENTARY INFORMATION}

The online version contains supplementary material available at https://doi.org/10.1134/S0026261721040068.

\section{OPEN ACCESS}

This article is licensed under a Creative Commons Attribution 4.0 International License, which permits use, sharing, adaptation, distribution and reproduction in any medium or format, as long as you give appropriate credit to the original author(s) and the source, provide a link to the Creative Commons license, and indicate if changes were made. The images or other third party material in this article are included in the article's Creative Commons license, unless indicated otherwise in a credit line to the material. If material is not included in the article's Creative Commons license and your intended use is not permitted by statutory regulation or exceeds the permitted use, you will need to obtain permission directly from the copyright holder. To view a copy of this license, visit http://creativecommons.org/licenses/by/4.0/.

\section{REFERENCES}

Dos Santos, P.C., Fang, Z., Mason, S.W., Setubal, J.C., and Dixon, R., Distribution of nitrogen fixation and nitrogenase-like sequences amongst microbial genomes, $B M C$ Genomics, 2012, vol. 13, art. 162.

https://doi.org/10.1186/1471-2164-13-162

Gaisin, V.A., Burganskaya, E.I., Grouzdev, D.S., Ashikhmin, A.A., Kostrikina, N.A., Bryantseva, I.A., Koziaeva, V.V., and Gorlenko, V.M., "Candidatus Viridilinea mediisalina", a novel phototrophic Chloroflexi bacterium from a Siberian soda lake, FEMS Microbiol. Lett., 2019a, vol. 366, art. fnz043.

https://doi.org/10.1093/femsle/fnz043

Gaisin, V.A., Burganskaya, E.I., Grouzdev, D.S., Osipova, N.S., Ashikhmin, A.A., Sinetova, M.A., Krutkina, M.S., Bryantseva, I.A., Sukhacheva, M.V., Kochetkova, T.V., Koziaeva, V.V., Kalashnikov, A.M., and Gorlenko, V.M., "Candidatus Oscillochloris fontis": a novel mesophilic phototrophic Chloroflexota bacterium belonging to the ubiquitous Oscillochloris genus, FEMS Microbiol. Lett., 2019b, vol. 366, art. fnz097.

https://doi.org/10.1093/femsle/fnz097

Gaisin, V.A., Grouzdev, D.S., Krutkina, M.S., Ashikhmin, A.A., Sinetova, M.A., Osipova, N.S., Koziaeva, V.V., and Gorlenko, V.M., "Candidatus Oscillochloris kuznetsovii" a novel mesophilic filamentous anoxygenic phototrophic Chloroflexales bacterium from Arctic coastal environments, FEMS Microbiol. Lett., 2020, vol. 367, art. fnaa158.

https://doi.org/10.1093/femsle/fnaa158

Grouzdev, D.S., Burganskaya, E.I., Krutkina, M.S., Sukhacheva, M.V., and Gorlenko, V.M., Genome sequence of "Candidatus Viridilinea halotolerans" Chok-6, isolated from a saline sulfide-rich spring, Microbiol. Resour. Announc., 2019, vol. 8, art. e01614-18.

https://doi.org/10.1128/mra.01614-18 
Grouzdev, D.S., Rysina, M.S., Bryantseva, I.A., Gorlenko, V.M., and Gaisin, V.A., Draft genome sequences of "Candidatus Chloroploca asiatica" and "Candidatus Viridilinea mediisalina", candidate representatives of the Chloroflexales order: phylogenetic and taxonomic implications, Stand. Genom. Sci., 2018, vol. 13. https://doi.org/10.1186/s40793-018-0329-8

Hanada, S., The phylum Chloroflexi, the family Chloroflexaceae, and the related phototrophic families Oscillochloridaceae and Roseiflexaceae, in The Prokaryotes: Other Major Lineages of Bacteria and The Archaea, Rosenberg, E., DeLong, E.F., Lory, S., Stackebrandt, E., and Thompson, F., Eds., Berlin: Springer, 2014, pp. 515-532.

Heda, S.D. and Madigan, M.T., Utilization of amino acids and lack of diazotrophy in the thermophilic anoxygenic phototroph Chlorolexus aurantiacus, J. Gen. Microbiol., 1986, vol. 132, pp. 2469-2473.

https://doi.org/10.1093/femsle/fnaa 158

Ivanovsky, R.N. and Khatipov, E.-A.A., Evidence of covalent modification of glutamine synthetase in the purple sulfur bacterium Thiocapsa roseopersicina, FEMS Microbiol. Lett., 1994, vol. 122, pp. 115-119.

https://doi.org/10.1111/j.1574-6968.1994.tb07153.x

Kaulen, H. and Klemme, J.-H., No evidence of covalent modification of glutamine synthetase in the thermophilic phototropic bacterium Chloroflexus aurantiacus, FEMS Microbiol. Lett., 1983, vol. 201, pp. 75-79.

https://doi.org/10.1111/j.1574-6968.1983.tb00092.x

Keppen, O.I., Baulina, O.I., and Kondratieva, E.N., Oscillochloris trichoides neotype strain DG-6, Photosyn. Res., 1994, vol. 41, pp. 29-33.

https://doi.org/10.1007/BF02184143

Keppen, O.I., Baulina, O.I., Lysenko, A.M., and Kondratieva, E.N., A new green bacterium belonging to the Chloroflexaceae family, Microbiology (Moscow), 1993, vol. 62, pp. 179-185.

Keppen, O.I., Lebedeva, N.V., Troshina, O.Y., and Rodionov, Y.V., The nitrogenase activity of filamentous phototrophic green bacterium, Microbiology (Moscow), 1989, vol. 58, pp. 520-521.

Keppen, O.I., Tourova, T.P., Kuznetsov, B.B., Ivanovsky, R.N., and Gorlenko, V.M., Proposal of Oscillochloridaceae fam. nov. on the basis of a phylogenetic analysis of the filamentous anoxygenic phototrophic bacteria, and emended description of Oscillochloris and Oscillochloris trichoides in comparison with further new isolates, Int. J. Syst. Evol. Microbiol., 2000, vol. 50, pp. 1529-
1537.

https://doi.org/10.1099/00207713-50-4-1529

Klatt, C.G., Liu, Z., Ludwig, M., Kühl, M., Jensen, S.I., Bryant, D.A., and Ward, D.M., Temporal metatranscriptomic patterning in phototrophic Chloroflexi inhabiting a microbial mat in a geothermal spring, ISME J., 2013, vol. 7, pp. $1775-1789$.

https://doi.org/10.1038/ismej.2013.52

Nishihara, A., Thiel, V., Matsuura, K., McGlynn, S.E., and Haruta, S., Phylogenetic diversity of nitrogenase reductase genes and possible nitrogen-fixing bacteria in thermophilic chemosynthetic microbial communities in Nakabusa hot springs, Microb. Environ., 2018, vol. 33, pp. 357365.

https://doi.org/10.1264/jsme2.ME18030

Tang, K.-H., Barry, K., Chertkov, O., Dalin, E., Han, C.S., Hauser, L.J., Honchak, B.M., Karbach, L.E., Land, M.L., Lapidus, A., Larimer, F.W., Mikhailova, N., Pitluck, S., Pierson, B.K., and Blankenship, R.E., Complete genome sequence of the filamentous anoxygenic phototrophic bacterium Chloroflexus aurantiacus, BMC $\mathrm{Ge}$ nomics, 2011, vol. 12, p. 334.

https://doi.org/10.1186/1471-2164-12-334

Thiel, V., Hügler, M., Ward, D.M., and Bryant, D.A., The dark side of the Mushroom Spring microbial mat: life in the shadow of chlorophototrophs. II. Metabolic functions of abundant community members predicted from metagenomic analyses, Front. Microbiol., 2017, vol. 8, art. 943.

https://doi.org/10.3389/fmicb.2017.00943

Tourova, T.P., Spiridonova, E.M., Slobodova, N.V., Boulygina, E.S., Keppen, O.I., Kuznetsov, B.B., and Ivanovskii, R.N., Phylogeny of anoxygenic filamentous phototrophic bacteria of the family Oscillochloridaceae as inferred from comparative analyses of the rrs, $c b b L$, and nifH genes, Microbiology (Moscow), 2006, vol. 752, pp. 192200. https://doi.org/10.1134/S0026261706020135

van der Meer, M.T.J., Klatt, C.G., Wood, J., Bryant, D.A., Bateson, M.M., Lammerts, L., Schouten, S., Sinninghe Damsté, J.S., Madigan, M.T., and Ward, D.M., Cultivation and genomic, nutritional, and lipid biomarker characterization of Roseiflexus strains closely related to predominant in situ populations inhabiting Yellowstone hot spring microbial mats, J. Bacteriol., 2010, vol. 192, pp. 3033-3042. https://doi.org/10.1128/JB.01610-09

Translated by $A$. Oleskin 